\title{
COMPLEX NPI SYSTEMS: HITTITE DATA
}

\author{
ANDREI V. SIDELTSEV \\ Institute of Linguistics, Russian Academy of Sciences, Moscow; RGGU; MPGU
}

\section{ABS TRACT}

The paper explores the syntax of Hittite indefinite pronouns. It argues that Hittite NPIs licensed by different licensors (negation markers and conditionals) are phonologically and morphonologically identical, but behave differently in syntactic terms depending on the licensor. There are two points of syntactic difference. The first consists in the obligatory split of the phrase which is headed by the NPI licensed by the negation marker vs. the optional split of the phrase headed by the NPI licensed by the conditional. The second point of difference is that in the majority of cases NPIs licensed by conditionals are in front of the preverb whereas the dominating position of NPIs licensed by negation is between the preverb and the verb. This Hittite system is cross-linguistically rare. It is clearly distinct from the commonly described systems where one phonological NPI pronoun behaves syntactically in the same way when licensed by different licensors. It is remotely similar to the systems of the Russian type with different NPI pronouns licensed by different licensors. In Hittite, as different from, for example, Russian, the same NPI pronoun is licensed in certain non-veridical contexts, but, similarly to Russian, there is a difference between the conditional and negative licensing contexts. In Hittite the difference lies in the morphosyntax of the same pronoun whereas in Russian in the fact that different pronouns are licensed by conditional and negation structures. Thus Hittite and Russian instantiate different possibilities of complex NPI systems.

\section{[1] INTRODUCTION}

Hittite indefinite pronouns like kuiški 'someone' correspond to two taxonomical entities in the general literature: existential quantifiers in main positive clauses and negative polarity items (NPIs) in negative, interrogative and conditional clauses. The main difference is that existential quantifiers are not overtly licensed whereas NPIs are licensed by several operators, most commonly the negative operator, interrogative operator or conditional operator.

The contexts associated with NPIs which are termed non-veridical (Haspelmath 1997; Giannakidou 2011; Paducheva 1985, 2015). Here is a representative list of non-veridical contexts (Paducheva 2015, 136-8): 
(i) negation,

(ii) noun phrase with a universal quantifier,

(iii) multiplicity of actions or their habituality,

(iv) conditional,

(v) questions,

(vi) disjunction, i.e. disjunctive coordinators either...or,

(vii) modality: possibility and necessity,

(viii) future, both grammatical future intentions concerning the future,

(ix) doubt, supposition, irreality as well as just opinion,

(x) comparison.

The difference between existential quantifiers and NPIs is classically demonstrated by the English some (existential quantifier) in (1-a) vs. any (NPI) in (1-b), (1-c) and (1-d):

(1) a. I met someone yesterday.

b. Did you meet anybody interesting?

c. If I meet anybody...

d. I did not meet anybody.

In this paper I will introduce the Hittite data. Hittite is a dead Indo-European language belonging to the Anatolian group, attested in the 18th-13th century B.C. on the territory of modern-day Turkey. Hittite covers both syntactic contexts by the same series of indefinite pronouns which do not have any other functions, see (2-a) for existential quantifier, (2-b) for NPI licensed by negation and (2-c) for NPI licensed by conditional:

(2)

a. Ù-it=wa=mu kuiški Memišta

dream-INSTR=QUOT=me somebody.NOM.SG.C speak.3SG.PST

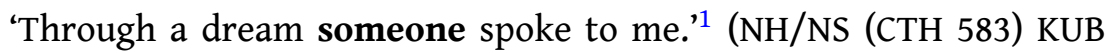
$15.5+$ obv. i 18)

b. kinuna $=\check{s ̌ s ̌ i}=k a n$ Apāt É-er GIŠ KIRI $_{6}$.GEŠTIN=ya

now=3SG.DAT=LOC that.ACC.SG.N house.ACC.SG.N vineyard=and

$\operatorname{ar}[h a] l \bar{e} \quad$ kuitki tat $[t] i$

Away PROHIB somehow take.2sG.PRS

[1] Here and elsewhere I follow standard most recent editions of the texts. 


\author{
'Now, that house(hold) and vineyard you should in no way take aw[ay] \\ from him!' (NH/NS (CTH 204) Msk. 73.1097 17-19) \\ c. takku ${ }^{\text {LÚ DAM.GÀr } k u i s ̌ k i} \quad$ Kuēnzi \\ if Merchant somebody.NOM.SG.C kill.3sG.PRS \\ 'If anyone kills a merchant...' (OH/OS (CTH 291.I.a.A) KBo 6.2 obv. i 3)
}

Sporadically relative pronouns/subordinators are used as NPIs in conditional clauses (3-a) and extremely rarely under negation (3-b), i.e. kuiš instead of kuiški 'someone':

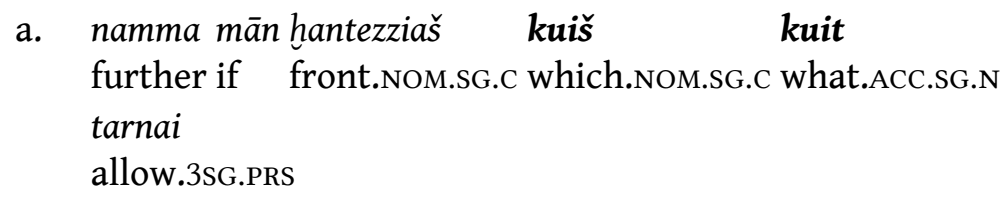

a. namma mān h̆antezziaš kuiš kuit

further if front.NOM.SG.C which.NOM.SG.C what.ACC.SG.N

tarnai

allow.3sG.PRS

'Further, if one of the forward men allows something in...' (MH/MS (CTH 262) IBoT 1.36 obv. ii 64)

b. ammug=a āššl ul kuit ha[tr]āeš

1SG.DAT.SG=but greeting.ACC.SG.N NEG which.ACC.SG.N write.2SG.PST

'To me you did not send any greetings' (MH/MS (CTH 199) ABoT 1.65 obv. 11)

It is curious that this secondary system of NPIs (see Sideltsev (2015b); Haug \& Sideltsev (To appear)) is much more limited with respect to the contexts in which it can appear than the NPIs of the kuiški type. Furthermore it never appears in unambiguous questions (Haug \& Sideltsev To appear).

The NPI class is usually understood to be morphosyntactically homogeneous in a particular language. In languages like English, some of the operators set out above license only one NPI - any. But more complex systems where several NPI pronouns are licensed in different contexts are also attested. Such a system is exemplified by Russian.

The two most common NPI pronouns in Russian belong to the series kto-nibud', kto-libo and kto by ni 'anyone' (Paducheva 2015, 135-9). kto-nibud' is licensed in the majority of the contexts listed above with very few exceptions (Paducheva $2015,135)$. See, for example, (4-a) for the doubt licensing context and (4-b) for the interrogative licensing context:
a. Bojus',
shto on
shto-nibud' naputal
be.afraid.1sG.PRs that 3sG.F.NOM something confuse.PST.M.SG
'I am afraid that he got something wrong' (Paducheva 2015, 138)
b. Kto-nibud' prixodil?
Anyone come.PST.M.SG
'Did anybody come?' (Paducheva 2015, 138) 
Unlike kto-nibud', kto-libo and kto by ni are licensed by only a fraction of the contexts licensing kto-nibud', namely by the negation, conditional, interrogative and comparative structures (Paducheva 2015, 144-5).

See, for example, (5) for the comparative licensing context:

(5) Jej s reb'onkom luchshe naxoditsa doma, chem

3SG.F.DAT with child.INSTR better be.INF at.home than

gde by to ni bylo

anywhere

'It is better for her to be at home with the child than anywhere else' ( $\mathrm{Pa}$ ducheva 2015, 146)

Kto-libo and kto by ni are not licensed in the following contexts (Paducheva 2015, 145-6):

- noun phrase with a universal quantifier,

- multiplicity of actions or their habituality,

- disjunction, i.e., disjunctive coordinators of the type either...or,

- modality: possibility and necessity,

- future, both grammatical future intentions concerning the future,

- doubt, supposition, irreality as well as just opinion.

In view of the fact that the prototypical NPI licensor is negation, it is particularly noteworthy that Russian NPIs of the kto-nibud' type are not licensed by negation (Paducheva 2015, 135) whereas the two other NPI types, kto-libo and kto by ni, are (Paducheva (1985, 218); Paducheva $(2015,143)$ ), as in

(6) Ivan ne videl tam kakix by to ni bylo/kakix-libo Ivan.NOM.SG NEG see.PST.M there any.GEN.PL

studentov

student.GEN.PL

'Ivan didn't see any students there' (Paducheva 2015, 143)

Even so, the use of kto-libo and kto by ni under negation is still very restricted (Paducheva 1985, 218-9). Mostly, a special class of pronouns of the type nikto 'nobody', named negative pronouns by Paducheva (2015, 134-5), cf. Giannakidou (2011), is used in negative clauses with negative concord on the verb.

(7) Nikto ne prishel

Nobody NEG come.PST.M

'Nobody came' 
Thus we see that the Russian NPI pronouns are mostly attested in complementary distribution and licensed by different operators.

In what follows I will explore another typological possibility which has not to my knowledge been discussed in general literature, namely, whether the same phonological NPI pronoun can behave differently, in syntactic terms, when licensed by different licensors. I will do so with the help of the Hittite data.

\section{[2] THE SENTENTIAL POSITIONS OF INDEFINITE PRONOUNS}

It has been shown that the Hittite indefinite pronouns, i.e. both existential quantifiers and NPIs, occur in sentence second and immediately preverbal position (Sideltsev 2014, 2015a,b), cf. Huggard (2015).

NPIs licensed by conditionals occupy both sentence second and immediately preverbal position whereas NPIs licensed by negation can only occur in immediately preverbal position, see (8):

$$
\begin{aligned}
& \text { nu mān DINGIR-lum apāddan šer šarnikzel ina É.GAL-lì } \\
& \text { CONN if god therefore over compensation.ACC.SG.N in palace } \\
& \text { ul kuitki šan (a)hta }
\end{aligned}
$$

NEG something.ACC.SG.N see.3SG.PST

'(As for that (fact) that Ammatalla [had taken] the eyes of the deity, (and that) she did not take care of [the deity],) if the deity does not seek any fine in the palace at all because of that...' (NH/NS (CTH 566) KUB 22.70 rev. 28-9)

If an NPI occurs in a clause with both the negation and conditional operators in (9), it is licensed by negation in immediately preverbal position and by the conditional in sentence second position:
a. mān andurza kuiški
${ }^{\mathrm{URUDU}} z a k k e-\check{s}$ ul karpanza
if inside some.NOM.SG.c bolt-NOM.SG.C NEG lifted.NOM.SG.C
'If inside some doorbolt has not been lifted,' (MH/MS (CTH 262) IBoT 1.36 obv. i $19-20$ )
b. našma É ${ }^{\mathrm{NA} 4} \mathrm{KIŠIB}$ kuitki haššanzi
or storehouse some.ACC.SG.N Open.3PL.PRS
'or if they open some storehouse' (MH/MS (CTH 262) IBoT 1.36 obv. i 19-20)

The only counterexample where the NPI in front of the negation is within its scope is provided by (10):

$$
\begin{aligned}
& {[(m \bar{a} n=w a r=a \check{s}=m u)]=k a n \quad \check{s u l}[(\text { liy })] a t \quad \text { kuwapi } \underline{\text { ul }}} \\
& \text { if }=\text { QUOT=3SG.NOM=1SG.ACC=LOC quarrel.3SG.PST when }
\end{aligned}
$$


'(When I wrote this to Urhitesub - if someone speaks thus: 'Why did you at first install him in kingship, but why do you now declare war on him in writing?' (I will answer:)) [(If he)] had in no way op[(pos)]ed me, (would they (i.e. the gods) really have made a Great King succumb to a petty king?' Because he has now opposed me, the gods have made him succumb to me by (their) judgement)' (NH/NS (CTH 81.A) KUB 1.1(+) rev. iii 76)

So, the only position both types of NPIs occupy is immediately preverbal position and it is this position I will explore in the remainder of this article.

[3] MORPHOSYNTACTIC DIFFERENCES BETWEEN DIFFERENT TYPES OF NPIS I will explore the differences in the syntactic behaviour of phonologically identical NPI pronouns with respect to their licensors.

\section{[3.1] Obligatory vs. Optional Split of the NP Headed by NPI}

The first difference consists in the obligatory split of the NP headed by the NPI and licensed by the negation marker (11-a) vs. the optional split of the NP headed by the NPI and licensed by the conditional, see (11-b) where the split occurs and (11-c) where it does not occur. The split consists in the fact that only the NPI may be found in immediately preverbal position whereas the noun phrase is in the left periphery of the clause:

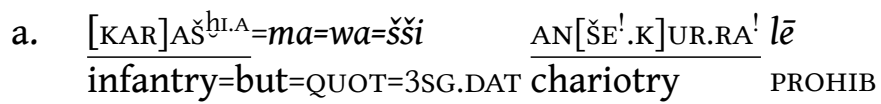

[kui]tki šanhanz $[i]$

something.ACC.SG.N seek.3PL.PRS

'But [absolu] tely no [in]fantry or chariotry shall be sought from him' (NH/NS (CTH 97) ABOT 57 32-33)

b. Mān ša É.NA ${ }_{4}=m a \quad$ hinqanaš waštul

If of stone.house=but death.GEN.SG.C crime.ACC.SG.N

kuiški waštai

somebody.NOM.SG.C sin.3SG.PRS

'If, however, anyone from the royal funerary structure commits a capital crime, ...' (MH/NS (252.A) KUB 13.8 obv. 11-12)

c. $m \bar{a}\left[\left(n\right.\right.$ tuk=ma $\left.\left.{ }^{\mathrm{m}} A\right)\right] l a k s ̌ a n d[(u)]-n \quad \check{s} E \check{s}=\mathrm{ka} \quad[(n a) \check{s}(m a \underline{s ̌ a}$

If 2SG.DATm=but Alaksandu-ACC.SG.C brother=your or of

MÁš=ka kuiški waqq)]āriy[(azi)]

family=your somebody.NOM.SG.C revolt.3sG.PRS

'[(But)] i[(f)] your brother [(or someone of your family re)]vol[(ts)] against [(you, A)]laksand[(u)]' (NH/NS (CTH 76.A) KUB 19.6+ obv. i $\left.78^{\prime}-79^{\prime}\right)$ 
So, in (11-b) the phrase ŠAÉ.NA $\boldsymbol{k}_{4}$ kuiški 'anyone from the royal funerary structure' is split with kuiški 'anyone' remaining in immediately preverbal position and ša É.NA 4 'from the royal funerary structure' raising to the left periphery.

It is important to bear in mind that in examples with negation markers like (11-a) all the noun phrase is not presupposed, and the existence of its referent is negated, but only the NPI is linearly between the negation marker and the verb, the rest of the NP is linearly to the left of the negation marker. Thus it is not the lack of presupposition itself that conditions the placement of the NPI between the negation and the verb as the lack of presupposition does not by itself determine the position of indefinite non-specific NPs between the negation marker and the verb.

\section{[3.2] Position vis-à-vis preverbs}

In the majority of cases NPIs licensed by conditionals are in front of the preverb (12-a) whereas the dominating position of NPIs licensed by negation is between the preverb and the verb ${ }^{2}(12-b)$ :
a. $n=a n=k a n$
:tapašša š
apiya kuiški
anda
CONN=3SG.ACC $=$ LOC fever.NOM.SG.C then some.NOM.SG.C in
wemiyazi
find.3sG.PRS

'(The fever that was established for His Majesty previously, will it be as long as he has not yet sat down in kingship? [the answers from two oracle procedures are conflicting] Or on which days they beat His Majesty with the huppialla, - for which matter we keep worrying in advance -) will some fever befall him then?' (1NH/NS (CTH 577.I) KBo 2.2 obv. i 45-46)

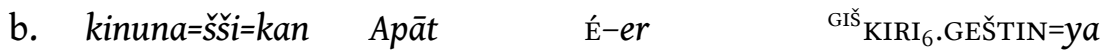 now=3SG.DAT=LOC that.ACC.SG.N house.ACC.SG.N vineyard=and $\operatorname{ar}[$ ha $] l \overline{\boldsymbol{e}} \quad$ Kuitki $\quad$ tat $[t] i$ away PROHIB somehow take.2SG.PRS
'Now, that house(hold) and vineyard you should in no way take aw[ay] from him!' (NH/NS (CTH 204) Msk. 73.1097 17-19)

Furthermore NPIs licensed by negation follow even those postpositions which govern them:

[2] See for NPIs licensed by negation Tjerkstra $(1999,173)$ with references. 


$$
\begin{aligned}
& \text { namma=za GIDIM damēdani memini šer ul } \\
& \text { then=REFL deceased other.DAT.SG matter.DAT.SG up NEG } \\
& \text { kuedanikki TUKU.TUKU-wanza } \\
& \text { something.DAT.SG angry.NOM.SG.C } \\
& \text { 'But furthermore (if) you, deceased, are angry because of no other matter...' } \\
& \text { (NH/NS (CTH 569.3.I) KBo 2.6+ obv. i 15'-16') }
\end{aligned}
$$

Here the postposition šer 'because of' governs the phrase damedani kuedanikki memini 'any other matter'. As a postposition, it is expected to follow all the phrases it governs but here it only follows damédani memini 'other matter' and unexpectedly precedes the NPI kuedanikki. In the MH/MS letter subcorpus, there are 8 cases $(89 \%)$ of the NPIs between the preverb and the verb and 1 case (11\%) where the preverb precedes boththe negation and the NPI. Roughly speaking, the same pattern is present in the broader corpus. For instance, in the NH/NS letter corpus negations in front of the preverb are attested 3 times (18\%) whereas negations between the preverb and the verb are attested 14 times (82\%). Thus, NPIs licensed by negation are attested in front of the preverb, but their position is most common between the preverb and the verb. It is also worth noting that preverbs as well as manner adverbs are the only constituents that can at least in some cases appear between the negation and the verb. All the NPs, including the complements of NPIs, irrespective of whether the negation has scope over them or not, are found to the left of the negation:

$$
\begin{aligned}
& n u=w a=m u=k a n \quad \text { ŠÀ KUR.KUR }{ }^{\mathrm{MEŠ}}[\text { hal }] k i \check{s} \quad \text { NU.GÁL } \\
& \text { CONN }=\text { QUOT }=1 \text { SG.DAT }=\text { LOC inside lands barley.NOM.SG.C NEG }
\end{aligned}
$$

'In my lands I do not even have barley' (NH/NS (CTH 176) KUB 21.38 obv. $\left.17^{\prime}-18^{\prime}\right)$

Here in (14) 'barley' is both within the scope of and to the left of the negation unlike the NPIs.

The statistics for NPIs licensed by conditionals is exactly the opposite: the position between the preverb and the verb for indefinite pronouns is attested 7 times (19\%) whereas the position in front of the preverb is attested 29 times $(81 \%)$ (cf. Huggard (2015); Brosch $(2014,84)$ ).

\section{[3.3] The scope and position of NPIs in the clause}

It was claimed (Huggard 2015) that the two positions of NPIs and existential quantifiers outlined above in Section [2] differ in terms of their specificity, scope, presupposition: second position NPIs and existential quantifiers are specific, presupposed and take wide scope whereas immediately preverbal NPIs and existential quantifiers are non-specific, non-presupposed and take narrow scope. 
Before I proceed with the discussion, a short definition of specificity is due. Specific indefinites have a particular referent, always allow the presupposition that the referent in question exists, even under negation, and they take wide scope, see von Heusinger (2011, 9-11); Paducheva (1985). Specific indefinites are also normally topical. ${ }^{3}$

Specificity is commonly understood in terms of scopal specificity or partitive specificity ${ }^{4}$ (von Heusinger \& Kornfilt 2005, 18).

In scopal specificity, 'the contrast between a specific and a non-specific reading of an indefinite is configurationally represented by scope interaction between the indefinite and some other operator, such as verbs of propositional attitude, negation or universal quantifiers' (von Heusinger \& Kornfilt 2005, 19).

$$
\text { Bill didn't see a misprint (von Heusinger \& Kornfilt 2005, 19). }
$$

The example is ambiguous between the following readings:

a. There is a misprint which Bill didn't see.

b. Bill saw no misprints (von Heusinger \& Kornfilt 2005, 19).

In (16-a), the NP a misprint is specific and has wide scope over negation whereas in (16-b) it is non-specific and has narrow scope.

Partitive specificity requires that an indefinite expression refer to a referent within a definite set:

a. 50 students entered the room. I knew two girls (out of 50 students). b. 50 students entered the room. They greeted two girls (already in the room) (von Heusinger 2011, 9-11).

In (17-a), the bolded indefinite is part of an already introduced set and is specific. In (17-b), the non-specific indefinite is not.

These are suggested to be the two key diagnostics of specificity - use of indefinites in episodic veridical contexts, i.e. in positive sentences describing concrete actions in the past (Paducheva 1985, 2015) and their use in partitive structures (Enç 1991).

[3] Although specific indefinite expressions can also be part of assertion, i.e. focus, see, e.g. Paducheva (1985, 216), as in Russian:

(i)

$$
\begin{aligned}
& \text { Vidimo, jejo vstrechal kto-nibudj iz rodstvennikov. } \\
& \text { perhaps 3sG.F.ACC meet.IMPF.PST.M somebody.NOM.SG from relative.GEN.PL } \\
& \text { 'It looks like one of (her) relatives met her.' (Paducheva 1985, 216) }
\end{aligned}
$$

[4] Specific indefinite noun phrases are sometimes understood to indicate familiarity of the speaker, on the one hand, and unfamiliarity of the hearer, on the other, with their associated referents (von Heusinger \& Kornfilt 2005, 18-9). In Haspelmath (1997), a distinction is drawn between specific knowns and specific unknowns. 
If applied to the Hittite data, both diagnostics show that there is no straightforward correlation between the position the existential quantifiers occupy and specificity: both second and preverbal existential quantifiers are attested in episodic contexts which force a specific referential status on the pronouns. All sentences come from the texts belonging to the genre of dreams where specific unknown referents are described with the help of existential quantifiers:

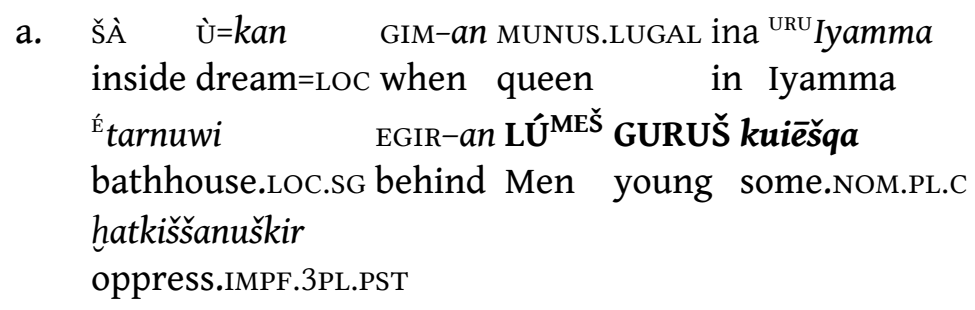

a. Š̀̀ Ù $k a n$ GIM-an MUNUS.LUGAL ina URU Iyamma inside dream=LOC when queen in Iyamma Étarnuwi EGIR-an LÚ ${ }^{\mathrm{MEŠ}}$ GURUŠ kuiēšqa bathhouse.LOC.SG behind Men young some.NOM.PL.C hatkiššanuškir oppress.IMPF.3PL.PST

'When in a dream some young men behind/at the back of the bathhouse in Iyamma (intended to) oppress the queen' (NH/NS (CTH 584) KUB 15.1+ obv. ii 6-8)

b. $n u=w a=m u=k a n$ anda kuedanikki pedi CONN=QUOT $=1$ SG.ACC $=$ LOC in $\quad$ some.LOC.SG place.LOC.SG pēhutet bring.3SG.PST

'He brought me in some place' (NH/NS (CTH 584) KUB 31.71 rev. iii! 7-8)

Here (18-a) provides an example of an immediately preverbal existential quantifier whereas (18-b) a second position existential quantifier. Both existential quantifiers are specific as they occur in episodic veridical contexts.

Similarly, both second position and immediately preverbal NPIs can take narrow scope vis-à-vis the conditional operator and be non-specific as is demonstrated by the following pair of contexts:

$$
\begin{aligned}
& \text { našma ana }{ }^{\mathrm{D}} \mathrm{UTU}-\check{S}=\mathrm{I} \text { kuiški } \\
& \text { or to Majesty=My somebody.NOM.SG.C or to progeny } \\
& { }^{\mathrm{D}} \mathrm{UTU}-\mathrm{S}=\mathrm{I} \text { ana LUGAL-UTTI ša KUR }{ }^{\mathrm{URU}}{ }_{\text {Hatti uwāi }}
\end{aligned}
$$

Majesty=My for kingship of land Hatti woe.ACC.SG.N bring.3sG.PRS '(And if you, Kuruntiya, do not observe these words of the tablet, and do not protect My Majesty and later the progeny of My Majesty concerning overlordship, or if you even desire the kingship of Hatti for yourself,) or (if) someone brings difficulties upon My Majesty or upon the progeny of My Majesty concerning the kingship of Hatti, (and you show him favour and do not combat him, then these oath gods shall eradicate you together with your progeny)' (NH/lNS (CTH 106.A.1) Bo 86/299 rev. iv 8-9) 
Here the indefinite pronoun in the second position is not topical or specific, as follows from the broader context: the set some members of which might refer to has not been introduced before. Its referential status and information structure are identical to those of non-specific immediately preverbal indefinite pronouns, which are determined by a similar context from the same text:

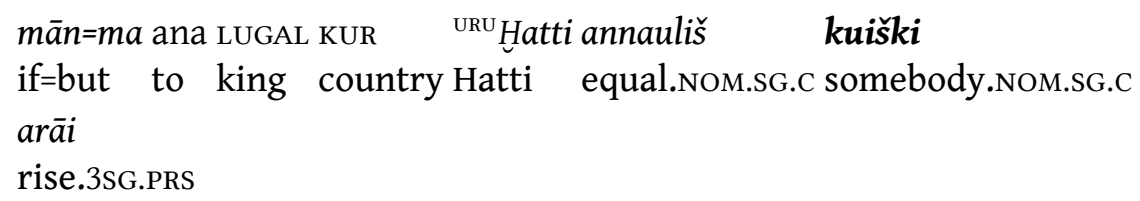

'But if someone of equal rank rises against the King of Hatti, (or if My Majesty goes on campaign out of the Lower Land on this side, then they shall raise 200 soldiers from him)...' (NH/lNS (CTH 106.A.1) Bo 86/299 rev. iii 39)

It might be argued that in (19) the NPI functions as the topic in the subsequent discourse whereas in (20) it does not and thus in (19) the NPI is specific whereas in (20) it is not. This conclusion can be based on the fact that the NPI in (19) is referred back to by the anaphoric pronoun in the subsequent discourse whereas such an anaphoric reference is absent in (20). However, since non-specific indefinite expressions can function as topics, see Paducheva $(1985,94)$, anaphora is not a reliable test of specificity. This very clearly follows from cases like (21) where no reference is made to a concrete group of people. Here the reference to the group's individual members does not entail specificity of the NPI, even though the NPI in question is referred to in the subsequent text:

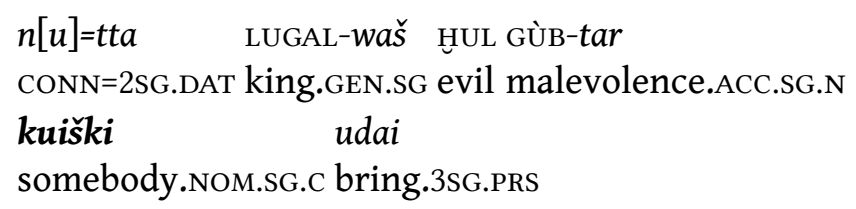

'(Whichever man he is, whether he is a Hittite citizen, or if he is of an equal country, or whether he is a common (lit. last) man, or whether he is a borderman, -) (if) any (of them) brings evil or malevolence regarding the king, - (do not hide him from the king ...)' (NH/NS (CTH 123) KBo 4.14 rev. iii 67-69)

As for the opposite scopal effect, i.e. wide scope of indefinite pronouns, it appears that both second and preverbal indefinite pronouns can refer back to an unknown referent within a concrete group, i.e. are specific unknown (Enç 1991).

In the following case the NPI is clause second: 


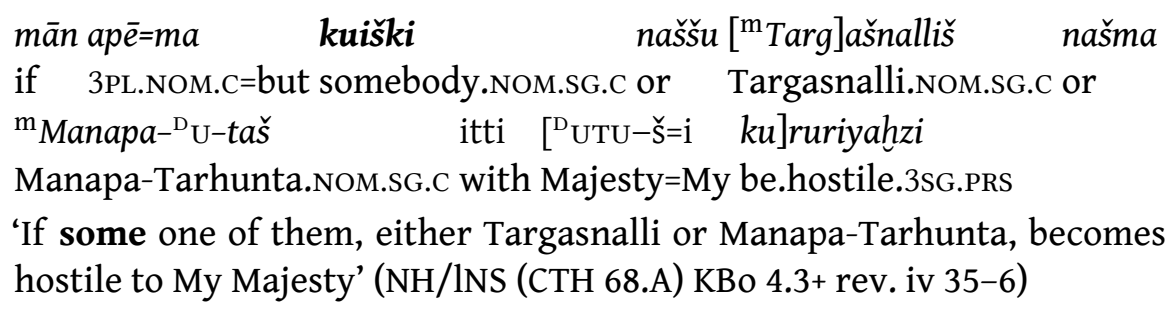

Here the NPI $k$ uiški 'somebody', generally expected to function as a genitive phrase, functions as a nominative phrase instead ( $a p \bar{e}$ 'they'). Still, it supports the explicit group reference, which is very clearly defined at the beginning of the paragraph (rev. iv 20-1 it is you who are the three free men: you, Kupanta-Kurunta, ManapaTarhunta, and Targasnalli'). The set of people that kuiški refers to is reiterated in the clause itself.

In the following case, the NPI is postverbal which is interpreted as immediately preverbal position of the NPI with subsequent verb movement (Sideltsev 2014, 2015a):

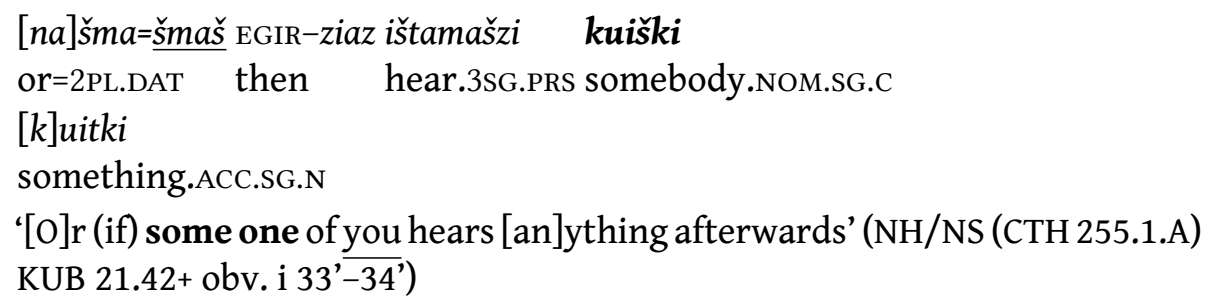

It is noteworthy that (23) attests two NPIs with a different information structure and specificity status. The referent of the subject kuiški is picked out of a definite group of people denoted by -šmaš 'you' in the same clause. The direct object [k]uitki is non-specific and part of the broad information focus of the clause. What is unexpected, if Huggard (2015) was right, is that both specific kuiški and non-specific kuitki are postverbal, not second position.

(24) is another very clear case where a quantifier phrase headed by an NPI is in immediately preverbal position but whose referent is picked out of a specific group present in the same clause:

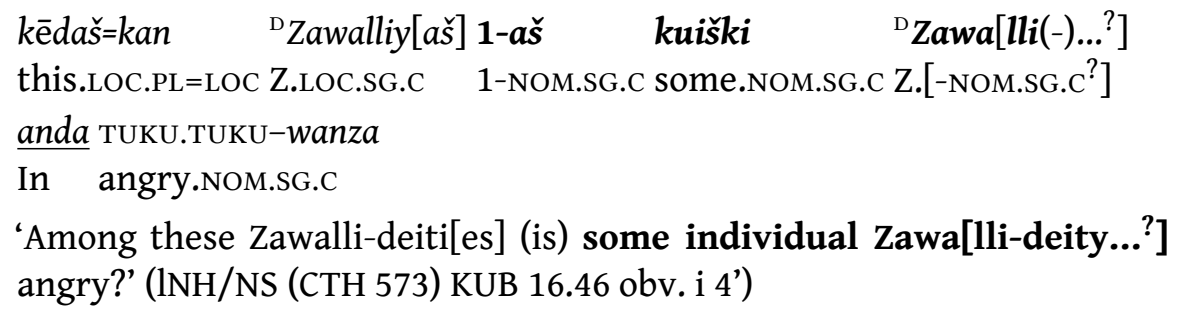

As is seen from the examples, such uses are often attested in conditional clauses 
and questions. In this case, NPIs are not within the scope of the conditional operator or question operator. If they were within the scope of the conditional, the nonveridical context would entail their non-specific interpretation, see Paducheva $(1985,2015)$; Abbott $(1995,342)$. It means they take wide scope over conditional or question operators. As follows from examples (22), (23) and (24) above, both second position and preverbal NPIs are specific and presupposed and take wide scope. In fact, if the pronouns take wide scope over the conditional, it means they are not licensed by it. Thus they are not NPIs, but rather existential quantifiers, just like the English somebody in negative and conditional sentences. For Hittite the solution is straightforward as the same phonological pronoun of the kuiški series serves both as an NPI and as an existential quantifier.

The analysis here follows Enç (1991) in that reference to an unknown member of a concrete group automatically implies specificity, i.e. the fact that the NP has a concrete referent, even if it is indefinite. However, the direct correlation between partitivity and specificity has been questioned in subsequent work (Abbott 1995; von Heusinger \& Kornfilt 2005).

Thus, Abbott $(1995,342)$ observes that there exist examples like (25), which are clearly nonspecific and yet would meet Enç's conditions for partitivity:
a. If you see one of my students at the lecture, please ask them to tell me about it.
b. They would find, at most, two of the items they are looking for in any of those stores (so they would go to Meijer's, where they would find them all).
c. Mary would not tell any of the secrets. (Abbott 1995: 342)

Thus, as von Heusinger \& Kornfilt $(2005,31)$ conclude, 'a partitive construction often induces a specific reading [...] However, this is not necessary: we also find partitives without a specific interpretation. Therefore, it is not partitivity that covers specificity, it is rather the explanation in terms of referential anchoring that explains specificity. It seems that specificity and partitivity are not equal concepts: partitivity is a complex referential property that consists of a definite part and an indefinite part. The definite part is the relation to an already introduced set, while the indefinite part is the choice out of this set. The choice can be specific or non-specific. In the latter case we would get non-specific partitives.'

If we follow this understanding, (22), (23) and (24) will be non-specific and outscoped by the operator, even though both occur in second and immediately preverbal position. Thus the scope of NPIs will be read off syntax: the operator c-commanding the NPIs will take wide scope over them and the NPIs will take narrow scope.

The same is true of NPIs licensed by the negative operator with one important difference: as the negation marker is normally immediately preverbal, only im- 
mediately preverbal NPIs are c-commanded by the negation marker and are thus outscoped by it, as is seen in (8). Second position NPIs c-command negation markers and outscope them, as in (9-a). The only case of inverse scope occurs in (10) where the NPI is outscoped by the negation which follows it. Another potentially relevant case similar to (10) involves a bare indefinite, i.e. a relative pronoun in form:

$$
\begin{aligned}
& \text { Mān ul kuit ide } \\
& \text { If NEG which.ACC.sG.N know }
\end{aligned}
$$

'But now about which my brother has expressed his disapproval to me I will not do again. Anything that displeases my brother I will not do to him, my brother, again.) If I do not know something (I might do such a displeasing thing to my brother. But because I already know I will certainly not do anything displeasing to my brother)' (NH/NS (CTH 176) KUB 21.38 rev. 10-13)

Here it follows from the context that we have an NPI which outscopes the negation operator. However, first the NPI is instantiated by a relative pronoun, not the normal morphologically marked NPI form which would be kuitki. As I showed in Sideltsev (2015b), relatives used as indefinites have been shown to have properties divergent from the morphologically marked NPIs. Second, the negation satisfies the second position pronoun requirement. As I showed in Sideltsev (2015c), in such cases the scope of negation always reconstructs back to its original position low in the tree. So the example is simply ambiguous.

Similarly to NPIs licensed by conditionals, NPIs licensed by negation, which pick out a referent out of a concrete group, are outscoped by negation whereas the concrete group is not. However, it appears that this strategy is common in many natural languages, see, for example, the following Russian dialogue where the negation outscopes the NPI:

$$
\begin{aligned}
& \text { - Nekotoryje iz vas uzhe byli na vystavke? } \\
& \text { some.NOM.PL from 2PL.GEN.PL already be.PST.PL on exhibition.LOC.SG } \\
& \text { - Net, nikto ne byl. } \\
& \text { No nobody NEG be.PST.M } \\
& \text { '- Were some of you at the exhibition already? - No, nobody was.' (Pa- } \\
& \text { ducheva 1985, 90-1) }
\end{aligned}
$$

In this example, the negated counterpart of nekotoryje iz vas 'some of you' is nikto iz nas 'none of us' (Paducheva 1985, 90-1).

Thus the scopal difference between the two classes of NPIs follows from their different syntax and does not by itself constitute another difference between NPIs licensed by the conditional and NPIs licensed by negation. 


\section{[4] CONCLUSION}

Hittite attests one phonologically and morphologically NPI pronoun which also serves an existential quantifier - kuiški. However, the pronoun behaves differently in syntactic terms depending on the type of licensor (negation markers vs. conditionals): when licensed by negation, the NPI pronoun has different syntax from the phonologically identical pronoun licensed by the conditional operator.

There are two points of syntactic difference. The first difference consists in the obligatory split of the NP headed by the NPI and licensed by the negation marker vs. the optional split of the NP headed by the NPI and licensed by the conditional. The second point of difference is that in the majority of cases NPIs licensed by conditionals are in front of the preverb whereas the dominating position of NPIs licensed by negation is between the preverb and the verb.

The Hittite system is cross-linguistically rare. It is clearly distinct from the commonly described systems where one phonological NPI pronoun is syntactically identical when licensed by different licensors. It is remotely similar to the systems of the type exemplified by Russian where different NPI pronouns are licensed by different licensors. In Hittite, unlike in Russian, only one NPI pronoun is licensed by the non-veridical contexts, but, in similarity to Russian, there is a difference between the conditional and negative licensing contexts. In Hittite the difference is in the morphosyntax of the same NPI whereas in Russian the difference lies in the fact that different pronouns are licensed by the conditionals, on the one hand, and by negation, on the other. Thus Hittite and Russian instantiate different possibilities of complex NPI systems.

\section{REFERENCES}

Abbott, Barbara. 1995. Some remarks on specificity. Linguistic Inquiry 26(2). 341347.

Brosch, Cyril. 2014. Untersuchungen zur hethitischen raumgrammatik. Berlin: De Gruyter.

Enç, Mürvet. 1991. The semantics of specificity. Linguistic Inquiry 22(1). 1-25.

Giannakidou, Anastasia. 2011. Positive and negative polarity items. In K. von Heusinger, C. Maienborn \& P. Portner (eds.), Semantics: An international handbook of natural language meaning, vol. 2, 1660-1712. Berlin: De Gruyter.

Haspelmath, Martin. 1997. Indefinite pronouns. Oxford: Oxford University Press.

Haug, Dag \& Andrei Sideltsev. To appear. Indo-Hittite syntax? In A. Kloekhorst and A. Lubotsky. The Proceedings of The Precursors of Proto-Indo-European: Indo-Hittite and Indo-Uralic Hypotheses. 
von Heusinger, Klaus. 2011. Specificity, referentiality and discourse prominence: German indefinite demonstratives. In I. Reich et al. (ed.), Proceedings of Sinn und Bedeutung 15, Saarbrücken, 9-30.

von Heusinger, Klaus \& Jacklin Kornfilt. 2005. The case of the direct object in Turkish: Semantics, syntax and morphology. Turkic Languages 9. 3-44.

Huggard, Mattyas. 2015. Wh-words in Hittite. University of California, Los Angeles. PhD dissertation.

Paducheva, Elena V. 1985. Sentence and its correlation with reality. Moscow: Nauka.

Paducheva, Elena V. 2015. Suspended assertion and nonveridicality. Russian Linguistics 39(2). 129-162.

Sideltsev, Andrei. 2014. Clause internal and clause leftmost verbs in Hittite. Altorientalische Forschungen 41(1). 80-111.

Sideltsev, Andrei. 2015a. Hittite clause architecture. Revue d'Assyriologie et d'archéologie orientale 109(1). 79-112.

Sideltsev, Andrei. 2015b. The riddles of Hittite indefinite pronouns. Altorientalische Forschungen 42(2). 199-275.

Sideltsev, Andrei. 2015c. Syntax of negations in Hittite. In Indo-European linguistics and classical philology XIX, Sankt-Peterburg, 824-837.

Tjerkstra, Françoise A. 1999. Principles of the relation between local adverb, verb and sentence particle in Hittite. Groningen: Styx.

AUTHOR CONTACT INFORMATION

Andrei V. Sideltsev

Institute of Linguistics, Russian Academy of Sciences, Moscow

RGGU

MPGU

acidelcev@gmail.com 